\title{
针刺运动疗法对前交叉韧带重建术后患者 等速肌力与运动能力的影响
}

\author{
严 文 ${ }^{1}$, 慕容嘉颖 ${ }^{2}$, 崔淑仪 ${ }^{1}$, 何婉雯 ${ }^{1}$, 庄 珣 ${ }^{3 *}$ \\ 1 佛山市第五人民医院,广东佛山 528200 ; \\ 2 广州体育职业技术学院, 广东广州 510650 ; \\ 3 广州中医药大学第一附属医院,广东广州 510405 \\ *通信作者: 庄珣,E-mail :zyjkkj@foxmail.com
}

收稿日期: 2020-04-20; 接受日期 : 2020-06-10

基金项目: 广东省医学科研基金项目 (A2016627); 佛山市十三五重点医学专科建设项目 (FSZDZK135033)

DOI: $10.3724 /$ SP.J.1329.2020.04006

开放科学 (资源服务) 标识码 (OSID):

摘要 目的: 观察针刺运动疗法对前交叉韧带 (ACL) 关节镜下重建术后患者等速肌力和运动能力的影响。 方法: 选择 2019 年 1 月-12 月佛山市第五人民医院收治的滕关节 ACL 完全断裂患者 50 例, 采用随机数字 表法分为对照组和观察组, 每组 25 例。2 组均接受膝关节镜下重建 ACL 手术。对照组术后给予传统运动疗 法, 包括主动屈膝训练、等长收缩训练、闭链静蹲练习; 每组训练后休息 $1 \mathrm{~min}$, 完成 3 组训练后休息 $2 \mathrm{~min}$, 每次训练做 3 个循环。观察组术后给予针刺运动疗法, 针刺患者健侧㮏痛穴, 进针行捻转平补平泻法(频率为 120 次/ $\mathrm{min}$, 以患者耐受为度, $1 \mathrm{~min}$ (次), 得气后进行主动屈膝训练、等长收缩训练、闭链静蹲练习, 训练方 法同对照组。针刺得气后进行下一组训练, 完成 3 组训练后休息 $2 \mathrm{~min}$, 每次训练做 3 个循环, 最后 1 个循环 训练完成后行针得气出针。以上 2 组均每日训练 1 次, $30 \mathrm{~min} /$ 次, 每周训练 $7 \mathrm{~d}, 7 \mathrm{~d}$ 为 1 个疗程, 共持续训练 4 个疗程。在治疗前及治疗 4 个疗程后, 采用量角器测量膝关节主动关节活动度; 采用 Lysholm 膝关节评分、 国际溙关节评分委员会 (IKDC) 主观膝关节评分评价膝关节功能; 采用等速肌力测试系统采集患侧滕关节伸 膝运动时股四头肌峰力矩 $(\mathrm{PT})$ 、平均功率 $(\mathrm{AP})$ 和总功 $(\mathrm{TW})$ 。结果: 治疗前, 2 组膝关节最大屈曲度、Lysholm 评分、IKDC 评分、股四头肌 PT、AP、TW 比较无明显区别, 差异无统计学意义 $(P>0.05)$ 。与治疗前比较, 治 疗 4 个疗程后 2 组滕关节最大屈曲度、Lysholm 评分、IKDC 评分、股四头肌 PT、AP、TW 均明显改善, 差异 具有统计学意义 $(P<0.05)$ 。与对照组比较, 观察组滕关节最大屈曲度、Lysholm 评分、IKDC 评分、股四头肌 $\mathrm{PT} 、 \mathrm{AP} 、 \mathrm{TW}$ 均明显改善, 差异具有统计学意义 $(P<0.05)$ 。结论: 针刺运动疗法可有效改善 ACL 重建术后患 者㮏关节主动关节活动度, 提高滕关节运动功能和股四头肌肌肉力量, 防止肌肉萎缩, 值得临床推广。

关键词 前交叉韧带; 重建术;膝关节;针刺运动疗法;等速肌力;运动能力

随着近年来体育运动的普及, 前交叉韧带 (ante-

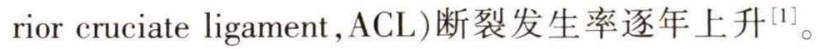
ACL 断裂会导致膝关节的运动稳定性降低, 患者步 态平衡受到严重影响, 容易跌倒。ACL 断裂虽可通 过重建手术进行修复,但术后早期需保持固定,患
肢运动量减少, 容易导致肌肉力量及运动能力下 降 ${ }^{[2-5]}$ 。因此, 最大限度促进 ACL 重建术后肌肉力量 及运动能力恢复是临床康复治疗所关注的重点。本 研究运用针刺运动疗法对 ACL 重建术后患者进行 康复治疗, 康复效果较好, 现报告如下。

引用格式: 严文, 慕容嘉颖, 崔淑仪, 等. 针刺运动疗法对前交叉韧带重建术后患者等速肌力与运动能力的影响 [J]. 康复学报, 2020,30(4): 275-279.

YAN W, MURONG J Y, CUI S Y, et al. Effect of acupuncture exercise therapy on isokinetic muscle strength and exercise ability of patients after anterior cruciate ligament reconstruction [J]. Rehabilitation Medicine, 2020,30(4):275-279. DOI : $10.3724 /$ SP.J.1329.2020.04006 


\section{1 临床资料}

\section{1 病例选择标准}

1.1.1 诊断标准 符合中华医学会《临床诊疗指南・ 物理医学与康复分册》中有关膝关节 ACL 损伤的诊 断标准 ${ }^{[6]}$ 。

1.1.2 纳人标准 (1) 符合上述诊断标准; (2) 单侧 单纯 ACL 损伤 ${ }^{[7]}$; (3) 年龄: $25 \sim 45$ 岁; (4) 术后病 程: 2 周 3 个月; (5) 无严重的器官疾病及精神疾 病; (6) 患者自愿参与,并签署知情同意书。

1.1.3 排除标准 (1) 术后病程 $>3$ 个月; (2) 合并 其他膝关节损伤 ${ }^{[8]}$; (3) 处于妊娠或哺乳期的女性 ; (4.)曾接受过其他康复治疗; (5) 存在较严重的术后 并发症。
1.1.4 中止标准 (1) 患者依从性低,无法按要求完 成相关治疗; (2) 治疗过程中擅自接受其他康复治 疗 $^{[9]}$; (3) 治疗过程中发生较严重不良反应事件。

1.1.5 脱落标准 (1) 患者病情恶化, 无法继续观 察; (2) 患者因个人原因出院或转院; (3) 治疗期间并 发其他疾病 ${ }^{[10]}$ 。

\section{2 一般资料}

选取 2019 年 1 月一 12 月广东省佛山市第五人 民医院住院治疗的膝关节 ACL 完全断裂患者 50 例。按就诊顺序编号,采用随机数字表法分为对照 组和观察组,每组 25 例。本研究方案经佛山市第五 人民医院伦理委员会审核通过。2 组年龄、性别、术 后时间及损伤原因等一般资料比较,差异无统计学 意义 $(P>0.05)$, 具有可比性。见表 1 。

表 12 组一般资料比较 $(\bar{x} \pm s)$

Table 1 Comparison of general data between two groups $(\bar{x} \pm s)$

\begin{tabular}{|c|c|c|c|c|c|c|c|c|}
\hline \multirow{2}{*}{ 组 别 } & \multirow{2}{*}{$n$} & \multirow{2}{*}{ 年龄/岁 } & \multicolumn{2}{|c|}{ 性别 } & \multirow{2}{*}{ 术后时间/周 } & \multicolumn{3}{|c|}{ 损伤原因 } \\
\hline & & & 男 & 女 & & 运动性创伤 & 意外扭伤 & 其他 \\
\hline 对照组 & 25 & $34.21 \pm 3.86$ & 15 & 10 & $4.04 \pm 2.18$ & 9 & 7 & 9 \\
\hline 观察组 & 25 & $32.78 \pm 4.16$ & 13 & 12 & $3.84 \pm 1.99$ & 11 & 6 & 8 \\
\hline
\end{tabular}

\section{2 方 法}

\section{1 治疗方法}

2 组均接受 ACL 重建术, 并按外科, 常规进行治 疗和护理。术后开始接受不同运动疗法干预。

2.1.1 对照组 在常规治疗基础上接受传统运动 疗法干预。具体包括: (1) 主动屈膝训练: 进行主动屈 膝训练, 膝部出现疼痛后恢复伸展位, 重复 10 次为 1 组。(2) 等长收缩训练: 分别在膝关节伸直和最大 屈曲位时进行股四头肌等长收缩训练, 保持 $5 \mathrm{~s}$ 后 放松 $5 \mathrm{~s}$, 重复 10 次为 1 组。(3) 闭链静蹲练习: 患者 背部紧贴墙面, 弯曲膝关节到最大屈曲位, 保持 $5 \mathrm{~s}$ 后恢复站立位, 重复 10 次为 1 组。以上项目训练完 成 1 组后休息 $1 \mathrm{~min}$, 然后继续进行下一组训练, 完 成 3 组训练后休息 $2 \mathrm{~min}$, 每次训练做 3 个循环。

2.1.2 观察组 在常规治疗基础上给予针刺运动 疗法。选取患者健侧膝痛穴 (上肢平伸, 手心向下, 腕关节与肩关节连线中点), 采用 1.5 寸一次性针炎 针 (苏州医疗用品厂有限公司, 华伦牌 $0.25 \mathrm{~mm} \times$ $40 \mathrm{~mm}$ ) 常规消毒后单手进针直刺, 深度为 $0.8 \sim 1$ 寸 左右, 进针行捻转平补平泻法 (频率为 120 次 $/ \mathrm{min}$, 以患者耐受为度, $1 \mathrm{~min} /$ 次)。(1) 针刺主动屈膝训 练: 得气后进行主动屈膝训练。(2) 针刺等长收缩训
练: 按照上述方法针刺, 得气后再进行等长收缩训 练。(3) 针刺闭链静蹲练习: 按上述方法针刺, 得气后 进行闭链静蹲练习。针刺得气后进行下一组训练, 完成 3 组训练后休息 $2 \mathrm{~min}$, 每次训练做 3 个循环, 最后 1 个循环训练完成后行针得气出针。

以上 2 组均每日训练 1 次, $30 \mathrm{~min} /$ 次, 每周训 练 $7 \mathrm{~d}, 7 \mathrm{~d} /$ 疗程, 共持续训练 4 个疗程。

\section{2 观察指标}

2.2.1 膝关节主动关节活动度测量 采用量角器 测量膝关节主动关节活动度, 伸直位为 $0^{\circ}$, 患者主 动屈曲膝关节至最大角度, 测量 3 次, 取平均值 ${ }^{[11]}$ 。

2.2.2 膝关节功能评分 采用 Lysholm 膝关节评分 量表进行膝关节功能评分 ${ }^{[12]}$ 。主要包含跛行、负重、 绞锁、关节不稳、疼痛、肿胀、爬楼梯和下蹲等 8 项 指标。总分为 100 分, 评分越高, 膝关节功能越优。

2.2.3 滕关节功能主观评分 采用国际膝关节评 分委员会 (International Knee Documentation Committee, IKDC) 膝关节功能主观评分表进行膝关节功能 评分 ${ }^{[13]}$ 。主要包含症状、功能和运动 3 个方面共 10 项主观评价指标。总分为 100 分, 评分越高, 膝关节 功能越优。

2.2.4 等速肌力指标 采用等速肌力测试系统采 集患侧膝关节伸膝运动时股四头肌峰力矩 (peak 
torque, $\mathrm{PT}$ ) 、平均功率 (average power, $\mathrm{AP}$ ) 和总功 (total work, TW $)^{[14-16]}$ 。PT 是指在运动过程中肌肉收 缩时产生的最大输出力矩; AP 是指在运动过程中 单位时间肌肉产生功率; TW 是每 1 组动作中最大 的 1 次做功量。

\section{3 统计学方法}

采用 SPSS 21.0 统计软件进行统计学分析。计 量资料用 $(\bar{x} \pm s)$ 表示, 数据符合正态分布, 组内比较 采用配对 $t$ 检验, 组间比较采用独立样本 $t$ 检验。计 数资料用频率或构成比表示, 采用 $\chi^{2}$ 检验进行分 析。 $P<0.05$ 为差异有统计学意义。

\section{3 结 果}

\subsection{2 组治疗前后膝关节主动关节活动度比较} 见表 2。
表 22 组治疗前后㬵关节主动关节活动度比较 $(\bar{x} \pm s)$ 度

Table 2 Comparison of active joint mobility of knee joint between two groups before and after treatment $(\bar{x} \pm s)$

\begin{tabular}{cccc}
\hline 组 别 & $n$ & 治疗前 & 治疗后 \\
\hline 对照组 & 25 & $61.56 \pm 2.98$ & $103.56 \pm 5.08^{1)}$ \\
观察组 & 25 & $63.07 \pm 3.23$ & $112.74 \pm 4.65^{12)}$ \\
\hline
\end{tabular}

注: 与治疗前比较, 1) $P<0.05$; 与对照组比较, 2) $P<0.05$ 。

Note: Compared with before treatment, 1) $P<0.05$; Compared with the control group, 2) $P<0.05$.

\subsection{2 组治疗前后膝关节运动功能评分比较} 见表 3 。

\subsection{2 组治疗前后股四头肌等速肌力比较} 见表 4。

表 32 组治疗前后膝关节运动能力的比较 $(\bar{x} \pm s)$

Table 3 Comparison of knee movement ability between two groups before and after treatment $(\bar{x} \pm s)$

\begin{tabular}{|c|c|c|c|c|c|}
\hline \multirow{2}{*}{ 组 别 } & \multirow{2}{*}{$n$} & \multicolumn{2}{|c|}{ Lysholm 评分 } & \multicolumn{2}{|c|}{ IKDC 评分 } \\
\hline & & 治疗前 & 治疗后 & 治疗前 & 治疗后 \\
\hline 对照组 & 25 & $45.85 \pm 5.16$ & $72.12 \pm 4.17^{1)}$ & $50.63 \pm 5.87$ & $73.51 \pm 5.01^{1)}$ \\
\hline 观察组 & 25 & $43.73 \pm 4.62$ & $82.25 \pm 3.89^{1 / 2)}$ & $49.43 \pm 4.25$ & $85.56 \pm 4.72^{1) 2}$ \\
\hline
\end{tabular}

注: 与治疗前比较, 1) $P<0.05$; 与对照组比较, 2) $P<0.05$ 。

Note: Compared with before treatment, 1) $P<0.05$; Compared with the control group, 2) $P<0.05$.

表 42 组治疗前后股四头肌等速肌力比较 $(\bar{x} \pm s)$

Table 4 Comparison of isokinetic muscle strength of quadriceps femoris between two groups before and after treatment $(\bar{x} \pm s)$

\begin{tabular}{|c|c|c|c|c|c|c|c|}
\hline \multirow{2}{*}{ 组 别 } & \multirow{2}{*}{$n$} & \multicolumn{2}{|c|}{ 峰力矩 $/(\mathrm{N} \cdot \mathrm{m})$} & \multicolumn{2}{|c|}{ 平均功率/W } & \multicolumn{2}{|c|}{ 总功 $/ \mathrm{J}$} \\
\hline & & 治疗前 & 治疗后 & 治疗前 & 治疗后 & 治疗前 & 治疗后 \\
\hline 对照组 & 25 & $33.71 \pm 4.54$ & $56.77 \pm 6.06^{1)}$ & $29.72 \pm 2.85$ & $41.49 \pm 5.98^{1)}$ & $44.71 \pm 3.54$ & $66.77 \pm 5.06^{1)}$ \\
\hline 观察组 & 25 & $36.39 \pm 3.81$ & $62.34 \pm 5.83^{122)}$ & $31.15 \pm 3.02$ & $51.66 \pm 6.07^{122}$ & $46.39 \pm 2.81$ & $73.67 \pm 4.83^{1 / 2}$ \\
\hline
\end{tabular}

注: 与治疗前比较, 1$) P<0.05$; 与对照组比较, 2) $P<0.05$ 。

Note: Compared with before treatment, 1) $P<0.05$; Compared with the control group, 2) $P<0.05$.

\section{4 讨 论}

\section{1 针刺运动序法可有效促进 ACL 重建术后患者 肌肉力量恢复}

ACL 重建术后需对膝关节固定制动, 膝关节运 动减退, 产生肌肉去负荷, 导致下肢骨骼肌发生废 用性萎缩, 其中以股四头肌最为明显 ${ }^{[17]}$ 。股四头肌 是下肢最大的一块肌肉, 下肢大部分的运动功能都 需要股四头肌参与或者支撑, 股四头肌萎缩后不仅 影响移植物的愈合, 还增加膝关节的不稳定性及关 节松动的几率, 手术效果受到较大影响, 使膝关节 术后其他功能锻炼难以达到预期效果, 从而延缓康
复进程 ${ }^{[18]}$ 。因此, 加强下肢肌群特别是股四头肌的 肌力训练, 将有可能获得较好的康复效果。

中医学认为 ACL 重建术后肌肉萎缩主要是由 于术后血气凝滞, 影响到血液对肌肉的滋润, 从而 导致肌肉的萎软无力; 再加上滕关节的静止性制动, 进一步加重废用性肌萎缩。针刺运动疗法通过远端 经络辨证取穴, 在针刺的同时使患者主动或被动地 运动患部, 从而产生刺激肌肉力量募集的效果 ${ }^{[19-20]}$ 。 本研究应用不同运动疗法干预 ACL 重建术后患者, 结果显示, 2 组股四头肌 PT、AP、TW 较治疗前均明 显改善, 且观察组股四头肌 PT、AP、TW 均明显高于 对照组, 这提示针刺运动疗法能有效提高 ACL 重建 
术后患者膝关节屈伸肌群肌力。这可能与以下因素 有关: (1) 远端取穴针刺有助于促进血液循环, 调节 气血功能,得气后进行主动/被动运动锻炼有助于激 发神经肌肉系统募集更多的运动单位参与肌肉收 缩, 促使神经冲动出现协同作用,从而提升患膝膝

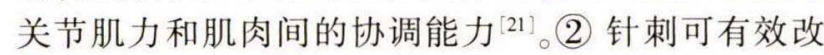
善患膝疼痛、肿胀问题, 患者膝关节活动度明显增 加, 膝关节活动范围扩大, 有助于促进肌肉收缩, 提

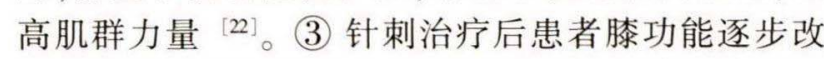
善, 患者能较好地从主动屈膝训练、等长收缩训练 过渡到闭链静蹲练习, 运动形式的不断进阶对负重 要求、膝关节稳定性控制能力要求更高, 这些项目 的训练更有助于强化患膝关节的本体感觉输人与 神经肌肉控制能力, 从而提高患膝屈伸肌群力量, 表 现出更优的肌肉募集效果。

\section{2 针刺运动疗法可有效提高 ACL 重建术后患者 㯟关节活动能力}

膝关节是人体下肢主要的运动关节, 其活动能 力直接影响到患者的步行能力和生活质量。前交叉 㓞带不仅能防止膝关节屈伸时胫骨过度前移, 还能 调节膝关节旋转运动功能, 与膝关节活动能力的稳 定性密切相关 ${ }^{[23]}$ 。本研究采取不同运动疗法进行干 预 ACL 重建术后患者, 结果显示, 2 组膝关节主动最 大屈曲度、Lysholm 膝关节评分、IKDC 主观膝关节 评分较治疗前均明显改善, 且观察组的改善程度较 对照组更加明显。这提示, 针刺运动疗法能有效改 善 ACL 重建术后患者的膝关节屈伸活动度, 提高膝 关节运动功能水平。这可能与以下原因有关: (1) 针 刺运动疗法具有 “动静” 结合, 调和 “阴阳” 的作用, 针刺远端穴位有助于疏通经络, 行气活血 ${ }^{[24]}$; 得气 后进行患侧肢体的主动/被动训练, 可进一步强化 患部气血运动, 产生叠加效应, 促进患膝关节微循 环恢复。(2) 针刺上肢神经节点, 通过传导通路反馈 信息到大脑高级神经中枢调控系统, 可引起应激性 调节, 调动中枢递质, 释放多种能量物质, 产生镇痛 效应、增强机体代谢的作用 ${ }^{[25]}$ 。本研究遵循传统针 刺疗法“远道刺” “巨刺”交叉取穴原则, 选择健侧膝 痛穴进行针刺, 可对失调的对侧膝关节进行调控, 促进机体达到阴阳平衡、气血通畅的状态。(3) ACL 重建术后常气血运行失利, 且对移植物存在免疫反 应, 膌关节容易出现血脉凝滞, 不通则痛, 不散而 肿, 患肢常出现肿胀、疼痛症状。针刺运动疗法不仅 可有效缓解患者疼痛、肿胀程度, 还可刺激远端经 络腧穴, 进一步调节全身气血、疏通经络, 达到治疗
下肢瘘证的作用,这样膝关节的运动功能就能得到 有效恢复 ${ }^{[26]}$ 。

\section{5 小 结}

运用针刺运动疗法对膝关节 ACL 重建术后患 者进行治疗,可有效改善膝关节主动关节活动度, 提高股四头肌肌肉力量和膝关节运动能力, 值得临 床推广应用。

\section{参考文献}

[1] 王宇. 等速肌力训练结合中医特色康复护理干预对滕关节骨 性关节炎疼痛影响临床观察 $[\mathrm{J}]$. 辽宁中医约大学学报, 2016, 18(10):208-211.

[2] JEON K Y. Comparison of knee laxity and isokinetic muscle strength in patients with a posterior cruciate ligament injury $[\mathrm{J}]$. J Phys Ther Sci, 2016,28(3): 831-836.

[3] 刘坤, 王训, 陈炜, 等. 等速肌张力测试系统的开发 [J]. 中国 医疗器械杂志, 2016,40(3): 157-160.

[4] PRILL R, MICHEL S, SCHULZ R, et al. Body composition and strength parameters in elite judo athletes 5 years after anterior cruciate ligament reconstruction $[\mathrm{J}]$. Int J Sports Med, 2019,40 (1) :38-42.

[5] EDELAAR L M, VAN DIEEN J H, VAN DER ESCH M, et al. Nonlinear relationship between isokinetic muscle strength and activity limitations in patients with knee osteoarthritis: Results of the Amsterdam-Osteoarthritis cohort $[\mathbf{J}]$. J Rehabil Med, 2017,49(7):598-605.

[6] 中华医学会. 临床诊疗指南. 物理医学与康复分册 $[M]$. 北京: 人民卫生出版社, 2005:85-88.

[7] 黄浩然,陈俊,王思哲, 等. 足部空间姿态评估分析系统在 ACL 重建前后步态分析中的应用 [J]. 中国骨与关节损伤杂志, 2018, 33 (12): 1255-1258.

[8]王健,王永健, 王海军, 等. 长病程前交叉韧带损伤后滕关节 继发改变研究 $[J]$. 中国运动医学杂志, 2019,38(4):276-280.

[9]目冰,黄秋, 张丹袞, 等. 术前短期家庭康复在全滕关节置换 中的应用研究 $[\mathrm{J}]$. 中国康复, 2018,33(2) : 129-132.

[10] 王笑青, 吴春丽, 李洛宜, 等. 中医微创针刀镜技术治疗早中 期滕关节类风湿关节炎临床研究 $[\mathrm{J}]$. 辽宁中医药大学学报, 2019,21 (12) : 157-160.

[11] 宋丹丹, 宋继东, 杨琨, 等. 全滕关节置换术前麻醉前、后滕 关节活动度与术后滕关节屈曲功能相关性研究 $[\mathbf{J}]$. 中国医 师杂志, 2018,20(3):324-326,331.

[12] 邹占亿, 窦思东, 跒行辉. 温针负阳陵泉联合等速肌力训练滕 关节骨性关节炎患者的疗效与对视觉模拟评分法和 Lysholm 滕关节评分的影响 $[\mathrm{J}]$. 世界中医药, 2018,13(9): 2292-2295, 2299.

[13] 何云, 王金裣, 司, 等. 膝关节镜联合 C 型臂治疗复发性髌骨 脱位疗效分析 $[\mathrm{J}]$. 实用骨科杂志, 2018,24(5):405-409.

[14] 万超,程俊华,王俊华,等. 内热针结合等速肌力训练对膝关 节德硬患者生物力学指标的影响 $[\mathrm{J}]$. 中医药导报, 2018,24 (18) : 74-76,111.

[15] 李吉如, 邓京捷, 廖红娟. 测力台上下肢肌力测试与滕关节等 
速肌力测试的相关性研究 $[\mathrm{J}]$. 体育科技, 2018,39(2):35-36, 38.

[16] 严文,黄文柱,王志军, 等. 不同角速度膝关节骨性关节炎患 者滕屈伸肌群等速肌力研究 $[\mathrm{J}]$. 广东医学, 2017,38(12): 1852-1855.

[17] 鞠秀奎. 青少年男子体操运动员主要关节的等速肌力特征 $[\mathbf{J}]$. 中国组织工程研究, 2016,20(46) : 6922-6929.

[18] 森炼,凌全寿,曾妙裳,等. 神经松动术的基础及临床康复研 究进展 $[\mathbf{J}]$. 康复学报, 2019,29(3): 73-78.

[19] JU S B,PARK G D. Effects of the application of ankle functional rehabilitation exercise on the ankle joint functional movement screen and isokinetic muscular function in patients with chronic ankle sprain [J]. J Phys Ther Sci, 2017,29(2):278281.

[20] 檚继康, 盖引莉, 华奌, 等. 中医配合锻炼在关节镜前交叉韧 带重建术后的应用 $[J]$. 中国中西医结合外科杂志, 2019,25 (1) :3-8.

[21] 林砚铭. 中药熏洗配合康复训练在前交叉韧带重建术后关节
功能恢复中的疗效观察 $[\mathrm{J}]$. 四川中医, 2017,35(4): 147148.

[22] 张晓圆, 黄红拾, 杨洁, 等. 术前等速离心训练和补充分离乳 清蛋白对前交叉韧带断裂患者股四头肌肌力和膝关节功能 的影响 [J]. 中国医学科学院学报,2017,39(6): 792-799.

[23] KIM K, JEON K, MULLINEAUX D R, et al. A study of isokinetic strength and laxity with and without anterior cruciate ligament injury [J]. J Phys Ther Sci, 2016,28(12) :3272-3275.

[24] CALEGARI L, BARROSO B F, BRATZ J, et al. Effects of aerobic training and strengthening in patients with heart failure $[\mathrm{J}]$. Revista Brasileira De Medicina Do Esporte,2017,23(2):123127.

[25] 王翔锋, 罗慧琴, 汤雯中, 等. 脉冲式注射在连续收肌管阻滞 用于滕关节术后镇痛中的疗效评价 $[\mathrm{J}]$. 康复学报, 2018,28 (5) $: 15-20$.

[26] 张洁,陈素莲,王春方, 等. 等速肌力训练结合半导体激光对 急性期膝关节骨性关节炎康复效果研究 $[\mathrm{J}]$. 国际生物医学 工程杂志, 2019,42(3):216-221.

\title{
Effect of Acupuncture Exercise Therapy On Isokinetic Muscle Strength and Exercise Ability of Patients after Anterior Cruciate Ligament Reconstruction
}

\author{
YAN Wen', MURONG Jiaying ${ }^{2}$, CUI Shuyi ${ }^{1}$, HE Wanwen ${ }^{1}$, ZHUANG Xun ${ }^{3 *}$ \\ ${ }^{1}$ The Fifth People's Hospital of Foshan, Foshan, Guangdong 528200, China; \\ ${ }^{2}$ Guangzhou Institute of physical education, Guangzhou, Guangdong 510650, China; \\ ${ }^{3}$ The First Affiliated Hospital, Guangzhou University of Traditional Chinese Medicine, Guangzhou, Guangdong 510405, China \\ *Correspondence: ZHUANG Xun, E-mail: zyjkkj@foxmail.com
}

\begin{abstract}
Objective: To observe the effect of acupuncture and exercise therapy on isokinetic muscle strength and exercise ability of patients after arthroscopic reconstruction of anterior cruciate ligament (ACL). Methods: A total of fifty patients with complete ACL rupture of knee joint treated in the fifth People's hospital of Foshan from January to December 2019. The patients were randomly divided into the control group and the observation group according to the method of random number table, with 25 cases in each group. Both groups received arthroscopic reconstruction of ACL. The control group was given traditional exercise therapy after operation, including active knee flexion training, isometric contraction training, closed-chain squatting training; each item rest one minute after training, and rest two minutes after training for three items, each training for three cycles. After operation, the observation group was given acupuncture exercise therapy, acupuncture at the knee pain points on the healthy side of the patients, and then the acupuncture was performed with the method of twirling, smoothing, toning and catharsis (the frequency was 120 times a minute, with the tolerance of the patients as the degree, one minute a time). After getting Qi (bring about the desired sensation), the patients were given active knee flexion training, isometric contraction training and closed-chain squat training, and the training method was the same as that of the control group. After acupuncture, the next training was carried out. After the training for three items, the patients took a rest for two minutes, and each training was done for three cycles. After the completion of the last cycle training, the needle was pulled out from the skin. The two groups were trained 30 minutes a time, once a day, 7 days a week and 7 days per course, continuous training for four courses. Before and after four courses of treatment, the range of motion of knee active joint was measured by protractor, the knee function was evaluated by Lysholm knee joint score and IKDC subjective knee score, and the peak torque (PT), average power (AP) and total work (TW) of quadriceps femoris during knee extension were collected by isokinetic muscle strength test system. Results: Before treatment, there was no significant difference in maximum flexion, Lysholm score, IKDC score, PT, AP and TW of quadriceps femoris between the two groups $(P>0.05)$. Compared with those before treatment, the maximum flexion, Lysholm score, IKDC score, PT, AP and TW of quadriceps femoris in the two groups were significantly improved after four courses of treatment, and the difference was statistically significant $(P<0.05)$. Compared with the control group, the maximum flexion of knee joint, Lysholm score, IKDC score, PT, AP and TW of quadriceps femoris in the observation group were significantly higher than those in the control group, and the difference was statistically significant $(P<0.05)$. Conclusion: Acupuncture exercise therapy can effectively improve the range of motion of knee joint, the motion function of knee joint and the muscle strength of quadriceps femoris after ACL reconstruction, and prevent muscle atrophy, which is worthy of clinical promotion.
\end{abstract}

KEY WORDS anterior cruciate ligament; reconstructive surgery; knee joint; acupuncture exercise therapy; isokinetic muscle strength; exercise ability

DOI : $10.3724 /$ SP.J.1329.2020.04006 